\title{
DESIGNING THE MARITIME DIGITAL COMPASS REPEATER HARDWARE AND ITS CONTROLLING ALGORITHM
}

DOI: $10.36724 / 2072-8735-2020-|4-7-5|-56$

\author{
Vu Xuan Hau, \\ Institute of Radioelectronics and Information Thechnoloies, \\ Ural Federal University named after First President \\ of Russia B.N. Yeltsin, Ekaterinburg, Russia, \\ hauxuanhd@gmail.com \\ Ivanov Vyacheslav Elizbarovich, \\ Institute of Radioelectronics and Information Thechnoloies, \\ Ural Federal University named after First President \\ of Russia B.N. Yeltsin, Ekaterinburg, Russia, \\ v.e.ivanovekt@gmail.com
}

Keywords: master compass, maritime digital compass repeater, gyrocompass repeater, azimuth, NMEAOI83 data, software, International Maritime Organization (IMO).

\begin{abstract}
A compass is a very important device onboard a ship. Using a compass, an operator is able to determine ship direction correctly, which contributes to fuel economy and safety. A compass was firstly invented in China during the reign of the Song dynasty to indicate the direction for travelling in a desert. Currently, compasses of different types are used for various purposes. There are satellite, magnetic, electrical, and other compasses. Up-to-data multifunctional highly reliable compasses are fabricated by Japanese, Russian, American and other producers. Despite the incredibly large offer of various compasses, the existing models are unsuitable for small marine vessels, and in most cases the price is very high. This article describes the results of research, hardware development and programming for the Maritime Digital Compass Repeater (MCRC). Algorithms of devices programming and actual results of MDCR tests are presented. MDCR design and tests results revealed that this repeater fully meets the technical requirements and may be installed and used shipboard. MDCR design is distinguished with reliability and beauty, stability in operation, simplicity to install and monitor. MDCR is programmed according to the optimal algorithm with two functions indicating the ship's azimuth and its turning rate. The research finding can contribute to an increase in the autonomy of Vietnam in marine technology. The equipment designed and developed is being implemented onboard many Vietnamese ships. To achieve the goals of the study, the authors applied both theoretical and empirical methods. The practical importance of the study is in the possibility to equip small ships and vessels navigating along internal routes with the designed compass system.
\end{abstract}

Information about authors:

Vu Xuan Hau, Postgraduate, Institute of Radioelectronics and Information Technologies, Ural Federal University named after First President of Russia B.N. Yeltsin, Ekaterinburg, Russia

Ivanov Vyacheslav Elizbarovich, Doctor of Technical Sciences, Professor of the Department of Radio Electronics and Telecommunications of the Institute of Radio Electronics and Information Technologies - RTF, Ural Federal University named after the first President of Russia B. N. Yeltsin Ekaterinburg, Russia

Для цитирования:

Ву Суан Хау, Иванов В.Э. Разработка аппаратного обеспечения морского цифрового ретранслятора компаса и построение алгоритма управления им // Т-Comm: Телекоммуникации и транспорт. 2020. Том I4. №7. С. 5I-56.

For citation:

Vu Xuan Hau, Ivanov V.E. (2020) Designing the maritime digital compass repeater hardware and its controlling algorithm. T-Comm, vol. I4, no.7, pp. 5I-56. (in Russian) 


\section{Introduction}

A shipboard compass system (CS) consists of three primary devices: Master compass (MC), Maritime digital compass repeater (MDCR), and a gyrocompass repeater (Fig. 1). MDCR is an important part of the CS [1-4].

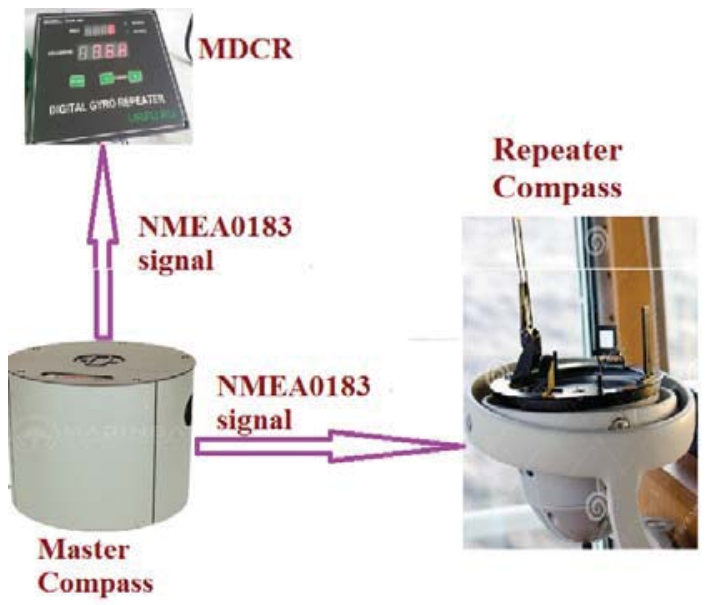

Fig. 1. CS devices connection diagram

In the ship's CS, the MDCR and the gyrocompass repeater perform the function of vessel navigation. According to the IMO standards, such important areas onboard a ship, as the engine control room, the watch-keeping cubicle, the captain's cabin shall be equipped with MDCR [5-7]. While MDCR is in operation, it is firstly, continuously receiving the NMEA0183 data packets $[8,9]$ from the MC, secondly, processing, and thirdly, displaying the course and ship turning rate by means of eight seven-segment LEDs.

\section{Designing hardware model for the MDCR}

MDCR block diagram is shown in Fig. 2, and its wiring diagram - in Fig. 3.

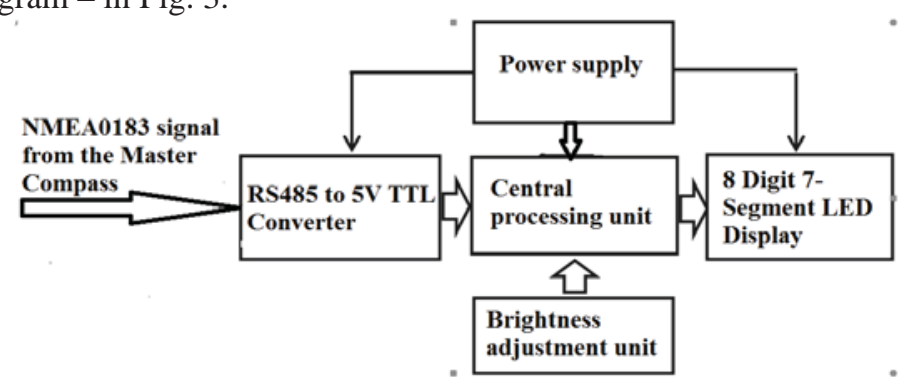

Fig. 2. The MDCR block diagram

MDCR includes:

Power Supply Unit, the function of which is to convert the 24 VDC power supply to 5 VDC to supply power to all elements of the device.

Central Processing Unit that collects the NMEA0183 data from the MC, processes and exports the ship's direction and velocity of rotation to eight seven-segment LEDs. For this device, the author chose ATMEGA16 microcontroller as the control center.

RS485 to 5V TTL Converter for communicating with the NMEA0183 standard, collecting NMEA0183 data and converting it from RS485 to TTL format.
Seven-Segment LED Indicator that is a combination of eight seven-segment LEDs, that indicate the ship's direction and its turning rate.

Brightness adjustment unit consisting of two buttons, (S2) and (S3), to adjust the brightness of the eight seven-segment LEDs.
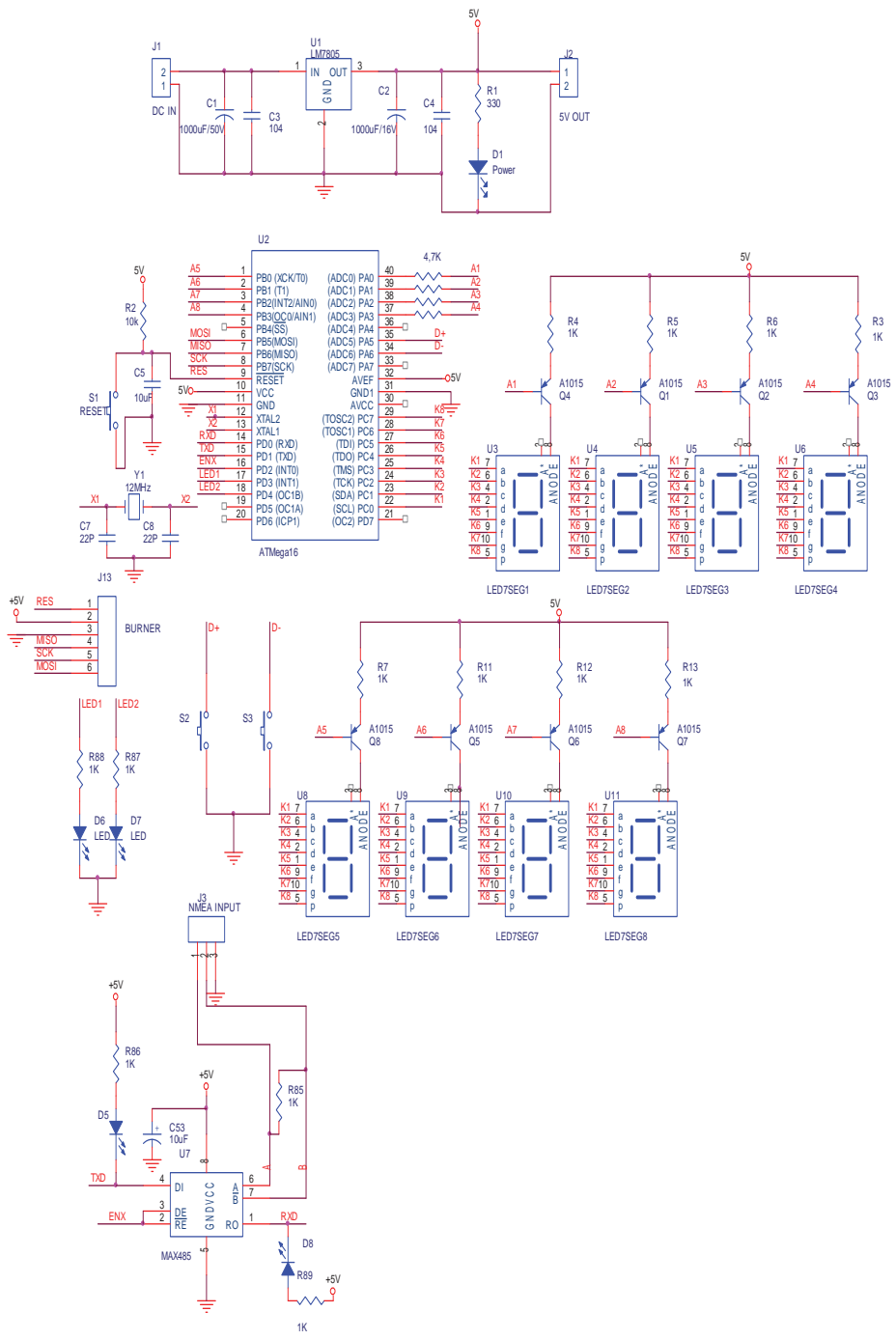

Fig. 3. MDCR wiring diagram

MDCR primary components are ATMEGA16 microcontroller [10], eight seven-segment LEDs for displaying the ship's azimuth and turning rate, the MAX485 microcircuit $[11,12]$ for receiving the NMEA0183 signals from the MC. NMEA0183 is a standard that defines a textual protocol for communication between and among the equipment that is used either for seagoing (usually navigational) or in trains [8, 9].

While MDCR is in operation, it is continuously receiving the NMEA0183 data packets from the MC, processing them, and displaying the ship's direction and turning rate by means of eight seven-segment LEDs. The mechanical body of MDCR was designed using Autocad and Corel software. To ensure corrosion resistance, the body had been fabricated from aluminum with an anti-electrostatic paint finish as per the relevant quality standards. The MDCR body drawings are shown in Fig. 4. Front view and results of model designing are shown in Fig. 5. Its primary parameters are: DC input voltage - from 12 to $36 \mathrm{~V}$; consumed 
direct current - not more than $0.2 \mathrm{~A}$; power consumption - not more than $4 \mathrm{~W}$; input signal - data packet NMEA0183 - in a standard RS485 format [12]; moisture resistance code - IPX6.

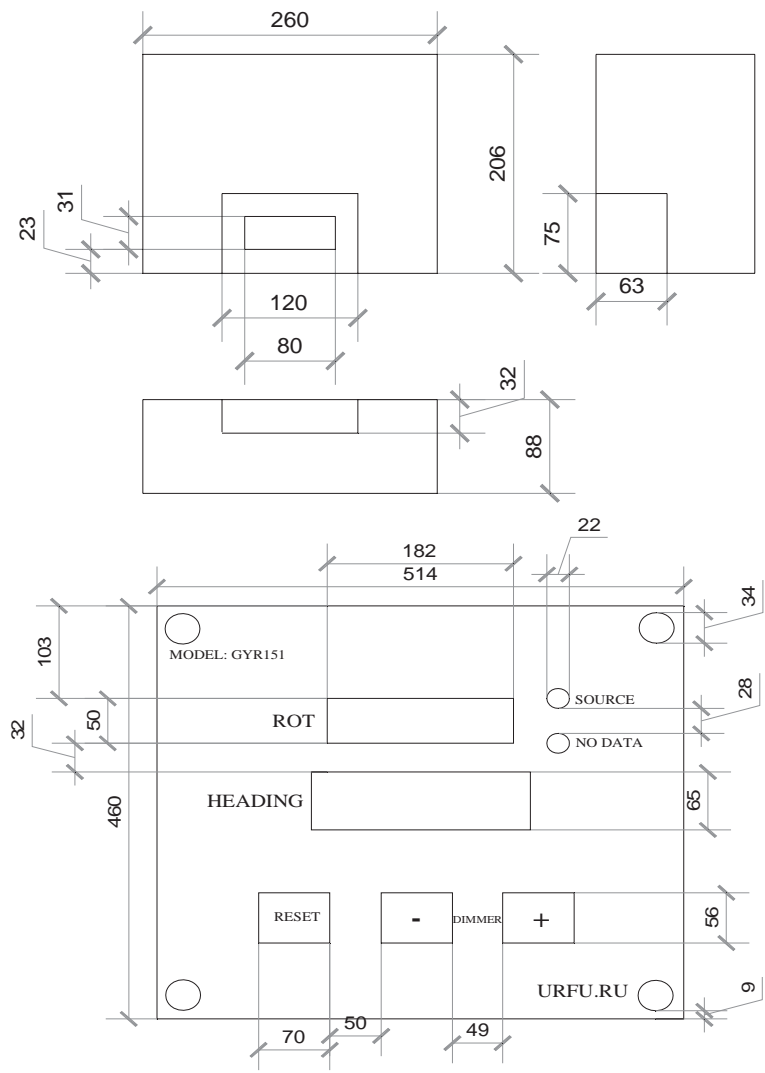

Fig. 4. MDCR body drawings
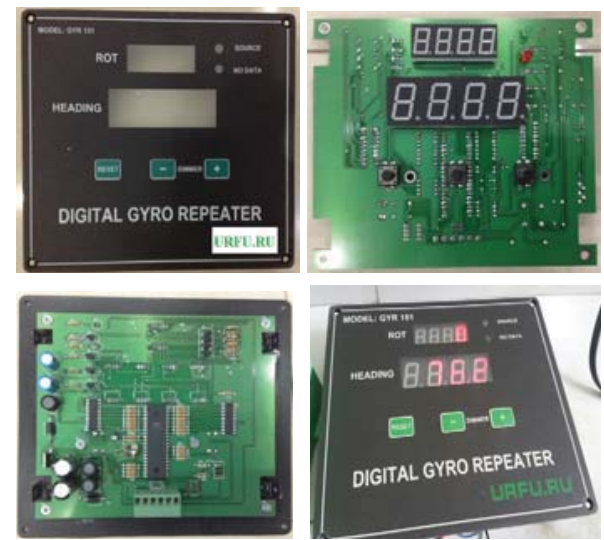

Fig. 5. The resulted MDCR design

\section{Design of MDCR software}

MDCR is programmed using CodeVisionAVR2.05 software [13]. MDCR algorithm structure is shown in Fig. 6.

\subsection{Algorithm of the program for received the MC signal}

The NMEA0183 data packet received from the MC takes the form of "\$HEHDT,XXX.X,T*YY" [8, 9]. The five basic characters of the form, "XXX.XX", stand for azimuth values to be displayed. The algorithm for NMEA 0183 data receiving includes such operations as: opening a receiving buffer of a sufficient size to accommodate the longest array of characters in accordance with NMEA 0183 specification for communication standard; the developed program uses the character array $A[i](i=0 \rightarrow 20)$; loading the NMEA0183 string of characters into a buffer; checking whether the character string in the buffer is a compass signal.

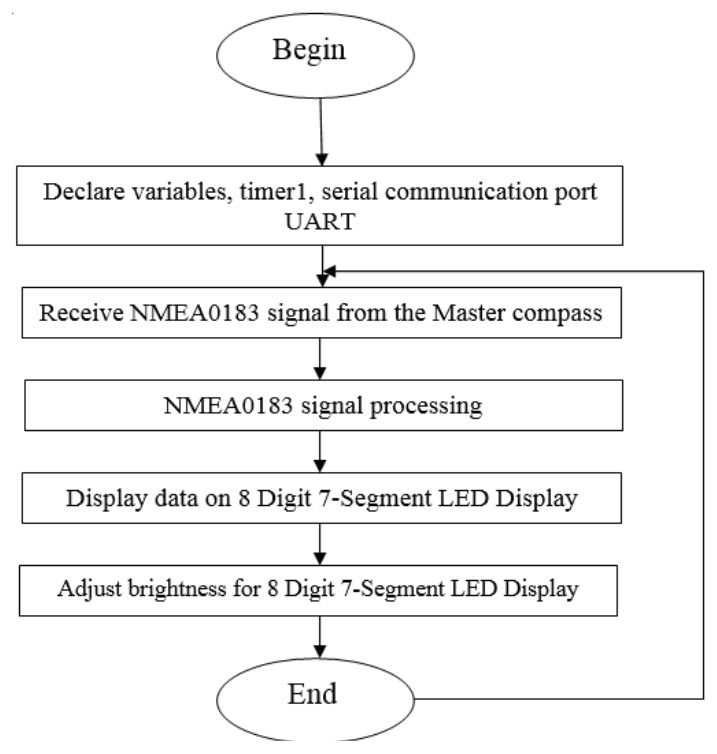

Fig. 6. MDCR algorithm

The receiving buffer is an array of character elements, the first character of which has index 0 . The microcontroller reads out each input character until it encounters the first "\$” character, at which the microcontroller is placing " $\$$ ” and the subsequent characters into the receive buffer, respectively. After loading the NMEA0183 signal, the program continues checking the character string in the buffer as a compass signal. In this case, the fourth, fifth and sixth characters " $H$ ", " $D$ ", and " $T$ ” in the receiving buffer are checked in their turn. During testing, after the first invalid character, the receiving buffer is flushed and reloaded. The algorithm only ends when the buffer receives the correct compass signal.

\subsection{Algorithm for processing the MC signals}

In the algorithm for receiving the NMEA0183 signal, the characters in the NMEA0183 packet are transferred into the data array A [i] $(i=0 \rightarrow 20)$. Therefore, the information "XXX.X" about the azimuth is placed in the elements of the array A [i] $(i=7 \rightarrow 11)$. For example, suppose the NMEA0183 bulletin received from the MC is "\$HEHDT,269.1,T*2F". Then $\mathrm{A}[7]=2$, $\mathrm{A}[8]=6, \mathrm{~A}[9]=9, \mathrm{~A}[10]=$ =.”, $\mathrm{A}[11]=1$.

In the processing program (Fig. 7) of NMEA0183 data, a real variable (angle), containing the azimuth value, is declared.

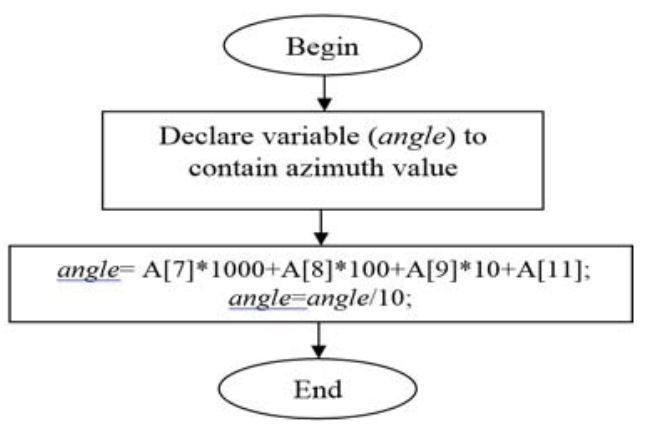

Fig. 7. MC signals processing algorithm 
If there is data from the MC, the algorithm executes 2 commands: angle $=\mathrm{A}[7] * 1000+\mathrm{A}[8] * 100+\mathrm{A}[9] * 10+\mathrm{A}[11]$,

angle $=$ angle $/ 10$

After executing these two commands, the value of the variable (angle) will contain the azimuth obtained from the MC.

\subsection{Algorithm for displaying azimuth by four seven- segment LEDs}

This algorithm (Fig. 8) first declares an integer-type variable $K$ and uses a timer to set the scan time of the seven-segment LEDs. When a timer interrupt occurs, the $K$ variable is incremented by 1 .

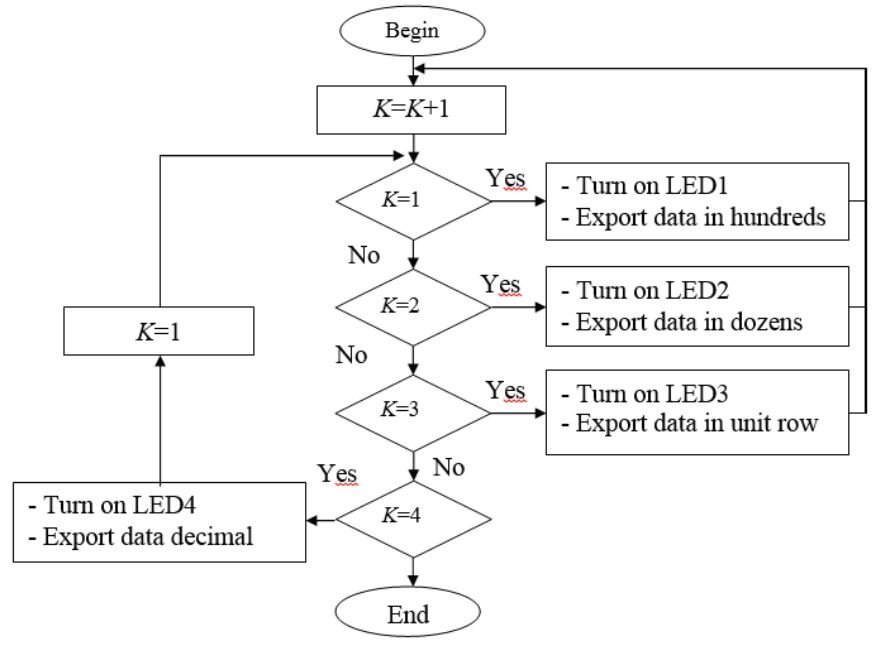

Fig. 8. Algorithm for displaying azimuth by four seven-segment LEDs

When the algorithm is started, the timer is activated. It starts counting from the time that was set at timer start. When the timer is full, the feeding of the seven-segment LED starts and at the same time the corresponding data is displayed. Wherein:

- $\mathrm{f} K=1$, then LED1 turns on and displays hundreds of degrees;

- $\mathrm{f} K=2$, then LED2 turns on and displays tens of degrees;

- $\mathrm{f} K=3$, then LED3 turns on and displays amounts of degrees;

- f $K=4$, then LED4 turns on and displays the decimal number after the decimal point.

The scan time for each 7-segment LED is $0.5 \mathrm{~ms}$, and the total scan time for the four 7-segment LEDs is $2 \mathrm{~ms}$. This is a short period of time sufficient for comfortable observation with the human eye.

\section{LEDs}

3.4. Algorithm for controlling brightness of seven-segment

The brightness adjustment (Fig. 9) of the seven-segment LEDs is carried out by two buttons (BUTON-) and (BUTTON+). Using timer 1, we create an algorithm to adjust the brightness of a seven-segment LED by changing its scan time. The brightness control algorithm declares the use of two variable quantities, (Brightness) and (Count). The (Brightness) variable represents light intensity, while the (Count) is used to adjust brightness. When the algorithm starts, the (Brightness) variable value is assigned a quantity of 15 (corresponding to the maximum bright- ness level). Let the Brightness gradually increase from 0 to 15 . At the same time, the condition (Count $<$ Brightness) is checked, and if it is satisfied, this value is further increased. But when Brightness $=15$, then all 15 LED cycles are on. This achieves the maximum brightness of the LEDs.

Press "BUTTON-“ to decrease brightness (Brightness) by one magnitude. For example, let Brightness =7, when Count $=7$, the LED is off. Then, on the next interrupts of the Timer1 the power cycles from 8 to 15 are not turned on, and the diode is powered for only the first 7 cycles. Note: LEDs must not be completely dark, so the Brightness level is limited from below: 3 to 15 .

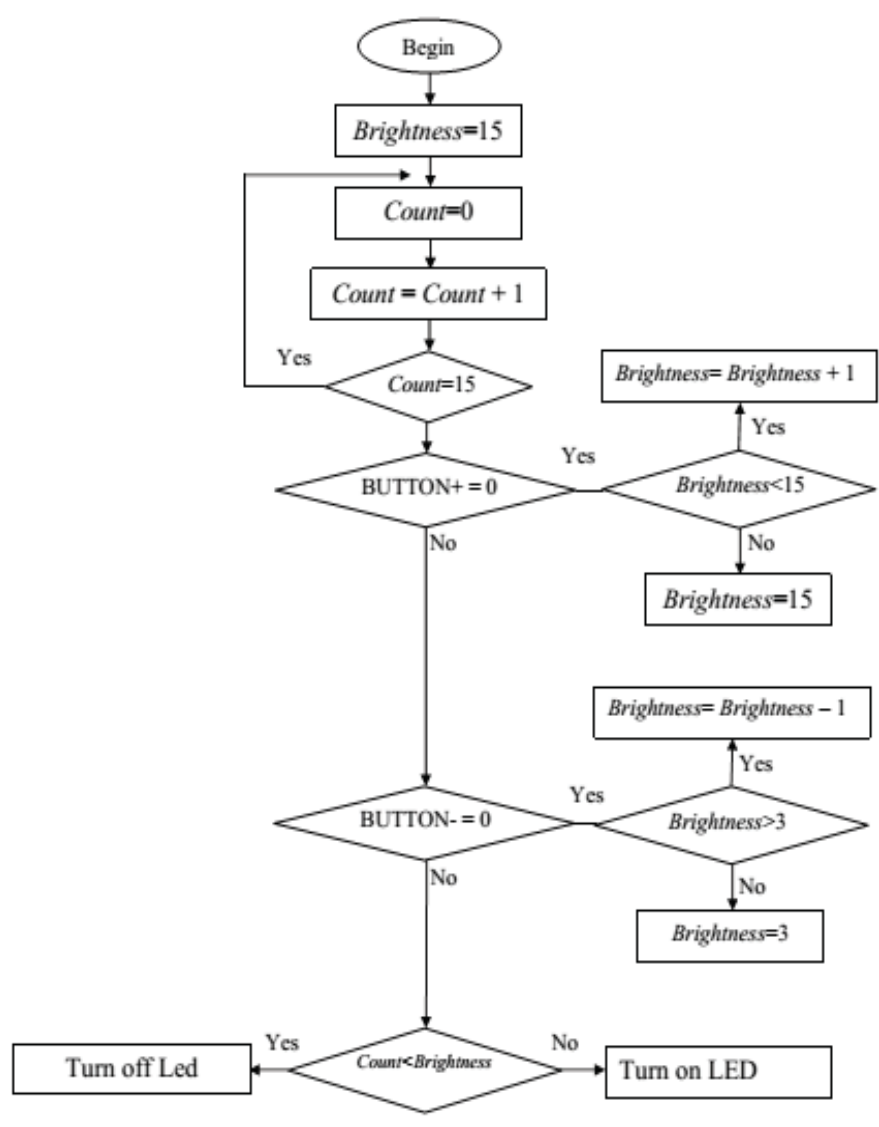

Fig. 9. Algorithm for controlling brightness of seven-segment LEDs

\subsection{Algorithm for calculating the ship's turn rate}

MDCR is also designed to display the ship's angular velocity with four seven-segment LEDs. The algorithm for calculating the ship's turning rate is shown in Fig. 10. To perform this calculation, one needs in using two NMEA0183 data packets from the MC at two consecutive points of time. The first algorithm waits for processing until the first NMEA0183 data packet is received. Upon receipt of the first NMEA1083 packet, the microcontroller calculates the first azimuth value $(A)$. Upon the receipt of the second NMEA0183 data packet, azimuth $(B)$ for the second point of time is calculated.

The packet transmission cycle of MC is $200 \mathrm{~ms}$. After calculating the second angle, the algorithm calculates the variation (increment) $(K)$ of the azimuth and calculates the turning rate of the ship $\omega=(K / 200) 1000$ degrees/sec. The found value $\omega$ is displayed on four seven-segment LEDs. 


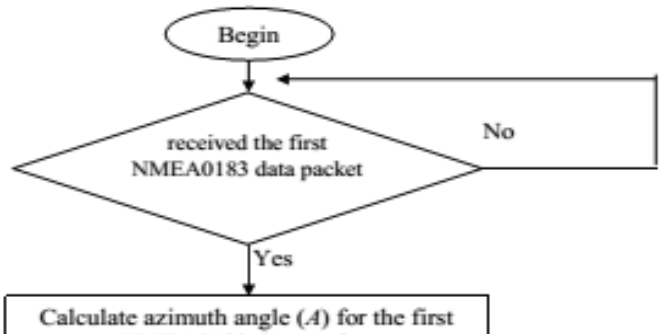

NMEA0183 data packet

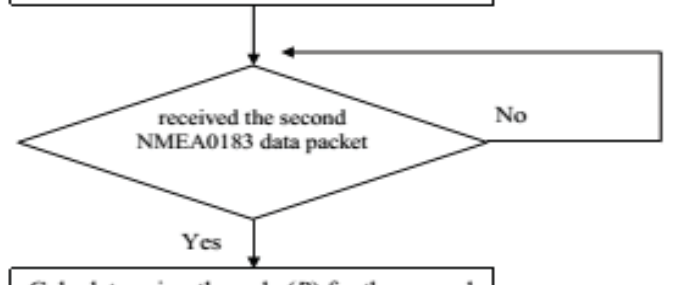

Calculate azimuth angle $(B)$ for the second NMEA0183 data packet

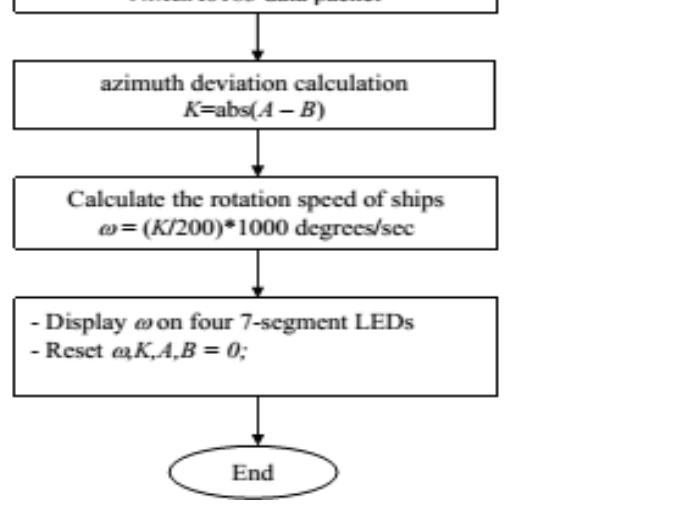

Fig. 10. Algorithm for calculating the ship’s turn rate

\section{MDCR test results}

To carry out the test, MDCR is connected with a USB-RS485 converter to a computer on which software (Fig. 11b), able to generate a compass signal in NMEA0183 format and transmit it to displaying devices is installed. The connection diagram of the computer and the test devices is shown in Fig. 11a.

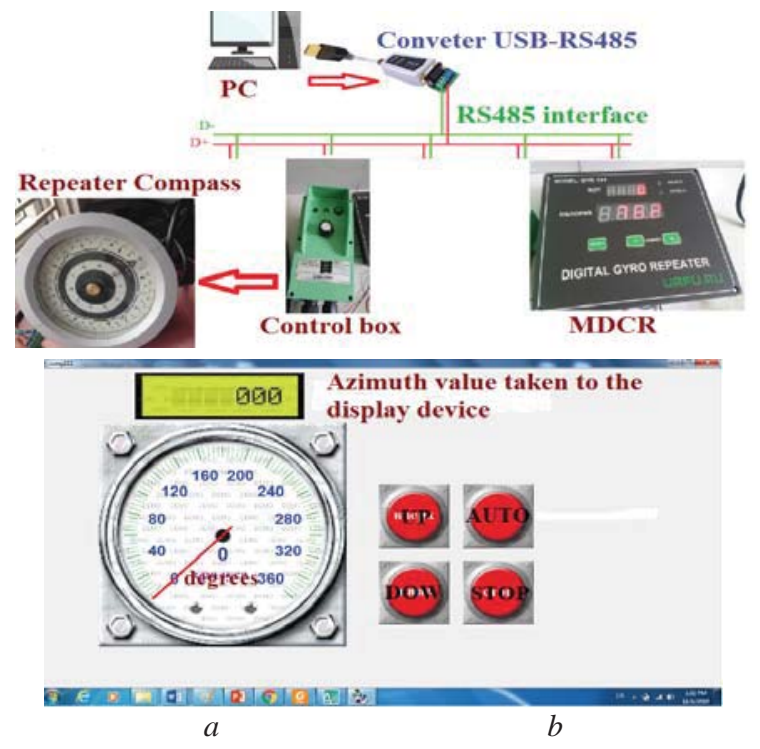

Fig. 11. Scheme of computer-MDCR connection (a), Software interface for MDCR testing (b)
The results of the displaying devices test presented in Table. 1 show that the displaying devices were designed in the full compliance with the technical standards and may be used on ships: the azimuth values displayed by the device and by the computer have slight deviations.

Table 1

Test results of displaying devices

\begin{tabular}{|c|c|c|c|}
\hline $\begin{array}{c}\text { PC based } \\
\text { indicator, } \\
\text { degrees }\end{array}$ & $\begin{array}{c}\text { The value shown } \\
\text { on the indicator } \\
\text { device, degrees }\end{array}$ & $\begin{array}{c}\text { Inaccuracy, } \\
\text { degrees }\end{array}$ & $\begin{array}{c}\text { Inaccuracy } \\
\text { estimation }\end{array}$ \\
\hline 0.0 & 0.1 & 0.1 & good \\
\hline 128.5 & 128.5 & 0.0 & good \\
\hline 250.1 & 250.2 & 0.1 & good \\
\hline 338.4 & 338.3 & 0.1 & good \\
\hline
\end{tabular}

\section{Conclusion}

The MDCR is beautiful and reliable by its design, stabile to operate, simple to install and monitor, and negligible by its error range (less than 0.1 degrees). The results of this study have made a tangible contribution to meeting the needs of Vietnamese shipboard equipment.

\section{References}

1. Ermolaev G.G., Andronov L.P., Zoteev E.S. (1970). Marine navigation / et al. 3rd ed. Revised. Moscow: Transport. 375 p. (in Russian)

2. Voronov V.V., Grigoriev N.N., Yalovenko A.V. (2004). Magnetic compasses, theory, design and deviation works. Elmore. 192 p. (in Russian)

3. Lukomsky Yu. A., Peshekhonov V. G., Skorokhodov D.A. (2002). Navigation and ship traffic control. Textbook. Elmore. 360 p. (in Russian)

4. Compass on a ship. URL: http://www.seaships.ru/ compass.htm. (in Russian)

5. IMO Resolution A.382(X) Recommendations on performance standards for gnetic ompasses. URL: https://puc.overheid.nl/nsi/doc/PUC_2469_14/1/

6. Magnetic compasses carriage and performance standards, A./Res.382(X).IMO(1977). URL: https://puc.overheid.nl/nsi/doc/PUC_2469_14/1/

7. Iternatinonal standard ISO 25862, Ships and marine technology - Marine magnetic compasses, binnacles and azimuth reading devices. First edition 2009-05-15, pp 1-7.

8. The NMEA0183 Protocol. URL: https://www.tronico.fi/ OH6NT/docs/NMEA0183.pdf.

9. National Marine Electronics Association. URL: http://www.nmea.org.

10. ATmega16 Datasheet - Microchip Technology. ttp://ww1.microchip.com/downloads/en/devicedoc/doc2466.pdf.

11. Max485 Datasheet. URL: http://www.alldatasheet.com/ datasheet-pdf/pdf/73463/MAXIM/MAX485.html.

12. RS-485, RS-422 and RS-232 interfaces. URL: https://www.bookasutp.ru/Chapter2_3.aspx. (in Russian)

13. CodeVisionAVR. URL: https://cxem.net/software/ codevisionavr.php. 


\section{РАЗРАБОТКА АППАРАТНОГО ОБЕСПЕЧЕНИЯ МОРСКОГО ЦИФРОВОГО РЕТРАНСЛЯТОРА КОМПАСА И ПОСТРОЕНИЕ АЛГОРИТМА УПРАВЛЕНИЯ ИМ}

Ву Суан Хау, Институт радиоэлектроники и информационных технологий, Уральский федеральный университет им. первого Президента России Б.Н. Ельцина, Россия, Екатеринбург, hauxuanhd@gmail.com

Иванов Вячеслав Элизбарович, Институт радиоэлектроники и информационных технологий, Уральский федеральный университет им. первого Президента России Б.Н. Ельцина, Россия, Екатеринбург, v.e.ivanovekt@gmail.com

\section{Аннотация}

Компас - очень важное устройство на корабле. С помощью компаса оператор может определить правильное направление судна, что способствует экономии топлива и безопасности. Компас впервые был изобретён в Китае при династии Сун, для указания направления движения по пустыням. В настоящее время различные типы компасов применяются в разных целях. Существуют такие компасы как: электрический, спутниковый, магнитный компас и др. Современные многофункциональные компасы с высокой надежностью выпускают производители из Японии, России, США и др. Несмотря на наличие, невероятно большого выбора среди компасов, существующие устройства не подходят для небольших судов, и их цена в большенстве случаев является очень весомой. В данной статье описываются результаты исследования, разработки оборудования и программирования для морского цифрового ретранслятора-компаса (МЦРК). Представлены алгоритмы программирования устройств и фактические результаты испытаний МЦРК. Основываясь на результатах разработки и тестирования МЦРК, было обнаружено, что он полностью соответствует техническим требованиям и может быть установлен и использован на судах. МЦРК отличается надежностью и красотой дизайна, устойчивостью работы, удобством установки и наблюдения. МЦРК программируется по оптимальному алгоритму с двумя функциями для указания азимута и скорости вращения корабля. Результаты исследования могут способствовать увеличению автономности Вьетнама в морских технологиях. Разработанное оборудование внедряется на многих вьетнамских судах. Для достижения цели работы, авторами были использованы два метода: теоретический и эмпирический. Практическая значимость исследования заключается в возможности оснащения разработанной компасной системой для небольших судов и судов, плавающих по внутренним маршрутам.

Ключевые слова: компас-мастер, морской цифровой ретранслятор-компас, репитер гирокомпаса, азимут, данные NMEA0I83, программное обеспечение, международная морская организация.

\section{Литература}

І. Ермолаев Г.Г., Андронов Л.П., Зотеев Е.С. и др. Морское судовождение. 3-е изд., перераб. М.: Транспорт, 1970.375 с.

2. Воронов В.В., Григорьев Н.Н., Яловенко А.В. Магнитные компасы, теория, конструкция и девиационные работы. СПб.: Элмор, 2004. $192 \mathrm{c.}$

3. Лукомский Ю.А., Пешехонов В.Г., Скороходов Д.А. Навигация и управление движением судов: учебник. СПб : Элмор, 2002.360 с. 4. Компас на морском судне [Электронный ресурс]. Режим доступа: http://www.seaships.ru/compass.htm.

5. IMO Resolution A.382(X) Recommendations on performance standards for magnetic compasses. https://puc.overheid.nl/nsi/doc/PUC_2469_I4/I/
6. Magnetic compasses carriage
and performance standards,
A./Res.382(X).
IMO

https://puc.overheid.nl/nsi/doc/PUC_2469_|4/I/

7. Iternatinonal standard ISO 25862, Ships and marine technology - Marine magnetic compasses, binnacles and azimuth reading devices

// First edition. 2009. № 05-I5. P. I-7.

8. The NMEA0I83 Protocol. https://www.tronico.fi/OH6NT/docs/NMEA0I83.pdf.

9. National Marine Electronics Association. http://www.nmea.org.

10. ATmegal6 Datasheet - Microchip Technology. ttp://wwl.microchip.com/downloads/en/devicedoc/doc2466.pdf.

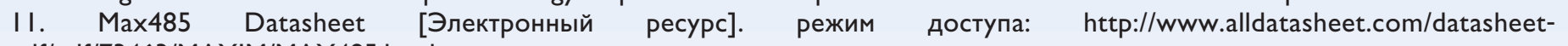
$\mathrm{pdf} / \mathrm{pdf} / 73463 / \mathrm{MAXIM/MAX} 485 . \mathrm{html}$.

12. Интерфейсы RS-485, RS-422 и RS-232 [Электронный ресурс]. - Режим доступа: https://www.bookasutp.ru/Chapter2_3.aspx.

13. CodeVisionAVR [Электронный ресурс].- режим доступа: https://cxem.net/software/codevisionavr.php.

Информация об авторах:

Ву Суан Хау, Аспирант, Институт радиоэлектроники и информационных технологий, Уральский федеральный университет им. первого Президента России Б.Н. Ельцина, Екатеринбург, Россия

Иванов Вячеслав Элизбарович, доктор технических наук, профессор кафедры радиоэлектроники и телекоммуникаций Института радиоэлектроники и информационных технологий - РТФ, Уральский федеральный университет имени первого Президента России Б. Н. Ельцина, Екатеринбург, Россия 